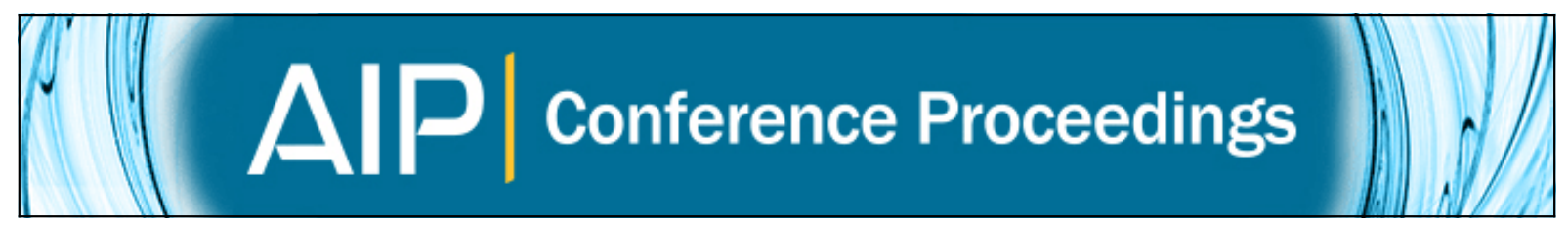

\title{
Preface: 2015 National Symposium of Mathematical Sciences
}

Citation: AIP Conference Proceedings 1750, 010001 (2016); doi: 10.1063/1.4954513

View online: http://dx.doi.org/10.1063/1.4954513

View Table of Contents: http://scitation.aip.org/content/aip/proceeding/aipcp/1750?ver=pdfcov

Published by the AIP Publishing

Articles you may be interested in

Preface from the Editors: International Symposium on Current Progress in Mathematics and Sciences 2015

AIP Conf. Proc. 1729, 010001 (2016); 10.1063/1.4946901

Preface: The 22nd National Symposium on Mathematical Sciences (SKSM22)

AIP Conf. Proc. 1682, 010001 (2015); 10.1063/1.4932408

Preface of the "Symposium on applied mathematics to computer science"

AIP Conf. Proc. 1648, 520001 (2015); 10.1063/1.4912731

Preface: 21st National Symposium on Mathematical Sciences (SMSK21)

AIP Conf. Proc. 1605, 1 (2014); 10.1063/1.4887555

Preface: 20th National Symposium on Mathematical Sciences

AIP Conf. Proc. 1522, 1 (2013); 10.1063/1.4801097 


\section{PREFACE: 2015 National Symposium of Mathematical Sciences}

Simposium Sains Matematik Kebangsaan 2015 (SKSM2015), or 2015 National Symposium of Mathematical Sciences, is the 23rd annual symposium organized by the Mathematics Association of Malaysia, or Persatuan Matematik Malaysia (PERSAMA). The symposium provides the opportunity for researchers, lecturers, students and practitioners to present their new findings in research as well as the platform for discussion on current topics and networking. This year's symposium was hosted by the Department of Mathematical Sciences, Universiti Teknologi Malaysia from 24 to 26 November 2015 at Pulai Springs Resort, Johor Bahru. The event attracted over 200 participants, out of which 120 papers have been selected for the final proceedings for publication by the AIP Publishing, New York. The selection of papers is made by the scientific committee based on peer review for original contribution, technicality and relevance of the contents to areas of mathematical sciences. The papers represent all disciplines of mathematics, namely, computational mathematics, industrial and applied mathematics, mathematics education, pure mathematics and statistics. In the preparation of the proceedings, the scientific committee would like to thank the committee members, staff and post-graduate students at the Department of Mathematical Sciences, Universiti Teknologi Malaysia for their commitment, dedication and hard work.

\section{Editors}

Shaharuddin Salleh

Noraini Aris

Normah Maan

Yudariah Yusof

Arifah Bahar

Zaitul Marlizawati Zainuddin

Mohd Hisyam Lee

Tahir Ahmad 